\title{
Reinforce Water and Climate Co-benefits in Actions to Control Soil Erosion
}

\author{
Lulu Zhang ${ }^{1}$ and Kai Schwaerzel ${ }^{2}$ \\ ${ }^{1}$ UNITED NATIONS UNIVERSITY Institute for Integrated Management of Material \\ Fluxes and of Resources \\ ${ }^{2}$ Thünen Institute of Forest Ecosystems
}

April 28, 2020

\begin{abstract}
Soil erosion resulted from human activities and associated land-use and climate change threaten our societal and economic thriving. Major policies and actions have been putting in place to protect soil from and mitigate soil erosion, such as in Europe and Asia. The main objective of our work is to synthesise the impacts of China's policy response to control soil erosion - the implementation of the Grain for Green Program - on water resources in a large erosion-prone dryland area. A combination of bottom-up (process-based knowledge) and top-down (watershed input-output relationship) approaches is applied to review the on-site and off-site hydrological impacts. The results highlight the critical linkages to water and climate co-benefits in China's soil conservation programme. It is indicated that the lack of water-saving strategy in measures of soil erosion control, such as the exclusion of plantation forest management, is the primary cause of the intensified water crisis in dryland China. A holistic understanding of the interconnected characters of soil-water-climate is vital for developing crosscutting policy responses to address soil erosion. Our work provides lessons-learned to the global long-term greening efforts in the degraded arid environment. We strongly recommend careful hydrological evaluation for drylands if tree-planting is used for soil conservation with wishful climate and water co-benefits.
\end{abstract}

\section{Reinforce Water and Climate Co-benefitsin Actions to Control Soil Erosion}

Lulu Zhang ${ }^{1 *}$ and Kai Schwärzel ${ }^{2}$

${ }^{1}$ United Nations University Institute for Integrated Management of Material Fluxes and of Resources (UNUFLORES), Dresden 01067, Saxony, Germany. Email: lzhang@unu.edu

2 Thünen Institute of Forest Ecosystems, Eberswalde 16225, Brandenburg, Germany. Email: kai.schwaerzel@thuenen.de

* Corresponding author: lzhang@unu.edu; Tel.: +49-351-7999-3806

\begin{abstract}
:
Soil erosion resulted from human activities and associated land-use and climate change threaten our societal and economic thriving. Major policies and actions have been putting in place to protect soil from and mitigate soil erosion, such as in Europe and Asia. The main objective of our work is to synthesise the impacts of China's policy response to control soil erosion - the implementation of the Grain for Green Program - on water resources in a large erosion-prone dryland area. A combination of bottom-up (process-based knowledge) and top-down (watershed input-output relationship) approaches is applied to review the on-site and off-site hydrological impacts. The results highlight the critical linkages to water and climate co-benefits in China's soil conservation programme. It is indicated that the lack of water-saving strategy in measures of soil erosion control, such as the exclusion of plantation forest management, is the primary cause of the intensified water
\end{abstract}


crisis in dryland China. A holistic understanding of the interconnected characters of soil-water-climate is vital for developing cross-cutting policy responses to address soil erosion. Our work provides lessons-learned to the global long-term greening efforts in the degraded arid environment. We strongly recommend careful hydrological evaluation for drylands if tree-planting is used for soil conservation with wishful climate and water co-benefits.

\section{Keywords}

Land restoration, the Grain for Green Programme, on-site water balance, off-site hydrological impact, SoilWater-Climate Nexus

Introduction

Soils are one of the most precious natural resources as they feed us and help our societies and economies to thrive. While the world population is projected to reach nearly ten billion in 2050 (UNDESA, 2019), increasing food demand has stressed global soils to produce more food and ensure food availability. Such pressure leads to a direct consequence that human activity and associated land-use change have caused a moderate to severe soil erosion of one-third of soil resources worldwide (Sommer et al. , 2017). Effective measures to protect soil from erosion and to conserve soils are thus key to enhance soil productivity for food security. Besides, soils have also pivotal roles in supporting the physical processes of the earth system and provision of other primary ecosystem services: they store, filter and transform water and nutrients, sustain a biological pool, and regulate climate and hydrology (FAO \& ITPS, 2015).

Soil erosion deteriorates soil quality by damaging soil physical structure and disrupting chemical and biological processes and cycles, which lowers soil's capacity to fulfil ecological and productive services and presents a major threat to the foundation of human needs. A recent assessment showed a trend of overall increment in global soil erosion with higher rates in Africa, South America, and Asia (Borrelliet al. , 2017). This urges national and regional policy responses to prevent and stop soil erosion, conserve degraded land, and mitigate the effects of soil erosion. For example, China has long put combating soil erosion as a core of the country's land sustainability (Bryanet al. , 2018). Several soil conservation programs are implemented in hotspot areas of soil erosion, such as the Three North Shelterbelt Project (TNSP) since the late 1970s and Grain for Green Program (GGP) since the late 1990s (Zhang \& Schwärzel, 2017a). In these programs, restoring vegetation is used as a key measure to control and reduce soil erosion in forms of, such as forestation on erosion-prone steep slopes and conversion of degraded slope farmland into woody plantations (Zhen \& $\mathrm{Hu}$, 2017). With an investment of US\$ 8.7 billion in GGP, $16,000 \mathrm{~km}^{2}$ eroded land is planted with trees, leading to an increase of forest cover by $25 \%$ over the last decades (Feng et al. , 2016). These measures turned out to be successful after decades in terms of soil erosion reduction and carbon sequestration in soil and biomass. The mean annual sediment yield of the Yellow River - one of the world's largest carriers of fluvial sediment - has been reduced by $95 \%$ in comparison to that of the 1950s (Xin et al. , 2015), while the carbon stock in soils has increased $25 \%$ within subsoil $(20-60 \mathrm{~cm})$ and $48 \%$ in topsoil $(0-20 \mathrm{~cm})$ over time since the implementation of GGP (Song et al. , 2014). This brings great co-benefits to mitigate climate change in the actions of controlling soil erosion.

However, a side-effect on hydrology of these programs has received great attention recently and led to intense domestic and international debates on forest-water nexus, namely the effects of forests on water cycle and water availability (e.g., Gustafsson et al. , 2019; Springgayet al., 2019; Sun et al. , 2006). Policymakers are accordingly confronted with challenges: Are the actions of GGP to reduce soil erosion and increase carbon sequestration at the cost of water availability? How can we reduce the negative impacts on water shortage and mitigate the trade-off of ecosystem services? The main objectives of this work are to (i) assess the impacts of GGP on the (on-site) water cycle and their feedback at (off-site) watershed scale; (ii) highlight the overlooked critical interlinkage to pursue synergy of ecosystem services; (iii) propose recommendations to reinforce co-benefits and mitigate trade-off in the actions to address soil erosion.

Materials and Methodology 


\subsection{Study Area}

The Loess Plateau is located in northwest China and an important part of China's dryland with a vast area of $620,000 \mathrm{~km}^{2}$ (Figure 1). It has three typical climatic zones: semi-humid in the southeast, semi-arid in the central part, and arid in the northwest. The average annual precipitation ranges from $200 \mathrm{~mm}$ in the northwest to $600 \mathrm{~mm}$ in the southeast (Wang et al. , 2017a). Approximate $55 \%-78 \%$ of annual precipitation falls during the main growing season from April to September (Zhang et al. , 2018b). Loess is typically arable due to features of fine-grain, loose texture, and high content of mineral nutrients, yet extremely erosion-prone (Wang et al. , 2017a). Cultivation of centuries without proper soil management makes the Loess Plateau a global hotspot of soil erosion (Fu et al. , 2011). The terrain of the Loess Plateau is characterised by thousands of ravines and gullies, $80 \%$ of which are dry and plagued by mountain torrents and flash floods during rainstorms. Moreover, the amount of fresh water per capita in the loess region is only $1 / 5$ of the national average, while the water availability for agriculture is less than $1 / 8$ of the national average (Wang et al. , 2017a). These facts make the Loess Plateau one of China's ecologically most vulnerable regions, thus a key area to implement the national eco-environment programmes. Soil erosion, frequent droughts, and water shortage are the most limiting factors for regional economic development.

[Figure 1]

\subsection{Sources of Data}

We set up field water balance measurements and undertook hydrological response analyses to investigate the impacts of afforestation or increase of forest cover on the (on-site) water cycle, as well as their feedback at (off-site) watershed scale in the Loess Plateau area. The applied technology and methods, used data, and analysis results are published in several peer-reviewed journal articles (Podlasly \& Schwärzel, 2013; Schwärzel et al. , 2018, 2020; Yu et al. , 2015; Zhang et al. , 2014, 2015). In this paper, we will compare the results and findings with other similar studies on the Loess Plateau regions for synthesis.

For the on-site impacts on the water cycle, we focus on the review of existing studies on measurements of water balance components, including soil water (SW) dynamic, evapotranspiration (ET), and seepage of black locust (Robinia pseudoacacia) plantation forests, which is the most common and widely used tree species for GGP's afforestation across the Loess Plateau due to its high drought resistance, nitrogen-fixing feature, and fast growth rate (Schwärzel et al. , 2020). To our best knowledge, despite great importance, there are very few numbers of field studies to quantify the whole water balance of black locust plantations (see the compilation in Schwärzel et al., 2018). Moreover, most of the existing studies only focused on a single component of water fluxes, such as either SW or ET; there is almost zero runoff generation under the black locust plantations, runoff is thus neglectable in the measurement of the existing studies while seepage is seldom quantified. It is also common for the Loess Plateau that SW dynamic under the black locust is observed against grass, shrubs, or cropland, whereas ET is measured without comparison to that of other land uses (e.g., natural grassland or cropland) (Schwärzel et al. , 2020). This hinders a holistic understanding of how afforestation alters water balance. To assemble a comprehensive view, it is necessary to use some additional studies on grassland or cropland in the region for comparing water flux changes, such as compare the amount of seepage under the plantation forests with the estimated groundwater recharge under tree and shrub plantations and agricultural land using multiple tracers. For the off-site hydrological impacts at watersheds, we use the published meta-studies to synthesise the effects of forest cover increase on water supply. Data on groundwater is deficient across the whole Loess Plateau due to a lack of monitoring. Streamflow, as an indicator of freshwater supply, is recorded over decades across a number of watersheds in the Loess Plateau and gauging stations along the tributaries and mainstream of the Yellow River. After the implementation of GGP, changes in long-term streamflow due to land-use and climate change have received great concerns and become a core topic of debate.

Results and Discussion

\subsection{Soil Water, Evapotranspiration and Seepage Dynamics}


Soil water is fundamental to support the growth of vegetation in dryland regions, thus vital for sustaining vegetation restoration on the Loess Plateau. To establish more water-conserving management of soil erosion in the Loess Plateau region, we need to know what the best attainable conditions in terms are of minimizing the water consumption of vegetation covers under a given climate. But there are only a very few comparative field studies - to our best knowledge - about the effects of black locust plantation and other vegetation on water fluxes. Therefore, Schwärzel et al. (2020) established one of the first paired plot hydrological field measurement studies with a neighbouring natural grassland. They measured water balance components (soil water, evapotranspiration, and seepage) of grassland (used as a baseline reference for comparison) and black locust forest. Schwärzel et al. (2020) found that due to the vertical niche (root system) separation between the overstory and understory, the SW under the multi-layer black locust plantation forest was much more deficient than that of natural grassland. The results of Schwärzel et al. (2020) matches the findings of three meta-studies on SW depletion under black locust plantations across 50-147 sites of the Loess Plateau. Deng et al. (2016) found that black locust decreased SW significantly within a soil depth of 0-100 cm - less significant in topsoils but much profound in subsoils $(>40 \mathrm{~cm})$ - in comparison to other shrubs- and grasslands. Jia et al. (2017) analysed the changes in SW content within a depth of $500 \mathrm{~cm}$. They found that the depth-averaged SW was much lower under black locust than cropland regardless of stand ages. Besides, they discovered that among different stand ages, the depth-averaged SW under black locust varies with a similar trend across different sites: it declines with increasing stand age in the first 20-25 years of growth and then slightly recovered with increasing stand age beyond 20-25 years. It is interesting to note that the large variations of SW mainly occur between the soil depth of 0 and $140 \mathrm{~cm}$ and it reaches a low level of SW around 140 $\mathrm{cm}$, while the SW stays at a rather consistent low level between 140 and $500 \mathrm{~cm}$, indicating soil desiccation and dry soil layer formation (Jia et al. , 2017). Liang et al. (2018) undertook a similar study as Jia et al. (2017). Except for the same conclusion that black locust plantations resulted in intense SW reductions in comparison to native vegetations, they also found that the SW under black locust plantations was positively correlated with the hydrothermal conditions (i.e., precipitation, temperature, and drought index); the extent of SW deficiency was correlated with stand age, especially in the areas with average annual precipitation below 500-550 mm (Liang et al. , 2018). All evidence indicates that black locust plantations dried up loess soils; if the local precipitation is insufficient to replenish SW, soil desiccation or dry soil layer formation will become an ecological problem of the Loess Plateau, bearing the great risk of soil degradation in a long run.

Evapotranspiration is a major part of water loss from the ecosystem through soil-vegetation-atmosphere interactions, thus directly affect the water balance. Schwarzel et al. (2020) used large weighable lysimeters and sapflow sensors to quantify the evapotranspiration of a 33-year black locust forest $\left(\mathrm{ET}_{\mathrm{f}}\right)$ and natural grassland $\left(\mathrm{ET}_{\mathrm{g}}\right)$. They found that black locust plantations remove much more water (in form of ET) than grassland out of the terrestrial ecosystem due to high water consumption of two-layer vegetation, namely understory evapotranspiration and overstory/tree transpiration; moreover, their results also showed that the seasonal water use of plantation forest $\left(\mathrm{ET}_{\mathrm{f}}\right)$ exceeds the seasonal precipitation $(\mathrm{P})$ of a normal year (Schwarzel et al. , 2020), intensifying water deficiency. This is in line with the observations of Jian et al. (2015) over five years and Jiao et al. (2018) over two years that the ratios between seasonal $\mathrm{ET}_{\mathrm{f}}$ and $\mathrm{P}$ were often over $100 \%$ (i.e., $\mathrm{ET}_{\mathrm{f}} / \mathrm{P}>1$ ). Until now, there is less than 15 published work on water consumption of black locust for the Loess Plateau. However, most of the (sapflow) transpiration estimations are highly likely biased due to using Granier's universal equation and a lack of specific calibration of parameters (Schwarzel et al. , 2018). Therefore, most previous work has significantly underestimated the transpiration rate of black locust. So far, only four experiments (Jian et al. , 2015; Maet al. , 2017; Schwarzel et al. , 2018; Zhang et al. , 2018a) have conducted reliable sapflow estimation and share an identical conclusion that black locust transpires much more water than thought. Both Ma et al. (2017) and Zhang et al. (2018a) have a close estimated rate of overstory transpiration. Ma et al. (2017) reported an average daily transpiration rate of 1.6-2.1 $\mathrm{mm}$ for a 15-year black locust stand, whereas Zhang et al. (2018a) estimated a daily rate of $1.7 \mathrm{~mm}$ for a 10-year stand. Due to the much younger ages, Ma's and Zhang's estimated values are slightly higher than that (a daily rate of $1.0 \mathrm{~mm}$ ) of Schwarzel et al. (2020) for a 33-year black locust plantation. Jian et al. (2015) reported a similar daily transpiration rate $(1.1 \mathrm{~mm}$ ) to Schwarzel et al. (2020) for a 28-year black locust forest. Although the more reliable estimated transpiration rates of black locust are much higher 
than the earlier reported ones, they only made a partial contribution to the increasing shortage of water in dryland China; another partital contribution sourced from understory vegetaition are rarely considered and investigated. Schwarzel et al. (2020) pointed out that contrary to the common belief, the understory was the main water consumer rather than the overstory in a black locust plantation of their study. Data of Jian et al. (2015), Jiao et al. (2018) and Schwarzel et al. (2020) showed that understory evapotranspiration (including soil evaporation) made up a large portion of water loss from black locust forests, accounting for $31 \%-59 \%$ of seasonal $\mathrm{ET}_{\mathrm{f}}$ or $27 \%-83 \%$ of seasonal $\mathrm{P}$. This results in much higher evapotranspiration or water consumption of black locust than that of grassland (Kimura et al. , 2006) or cropland (Yang et al. , 2014) on the Loess Plateau.

Seepage is the water downwards movement under vegetation root zone and considered as a meaningful indicator of groundwater recharge potential. However, investigations are rarely conducted under plantation forests on the Loess Plateau. Schwarzel et al. (2020) estimated the seasonal seepage under the grassland and black locust forest using three methods. All results showed that grassland can sustain a good level of seepage, while black locust produces negligible seepage in years with average rainfall. These results agree with the conclusions of the isotope- and tracer-based estimations of groundwater recharge under different land-uses on the Loess Plateau. Gates et al. (2011) used isotope and chloride tracer for estimation of the groundwater recharge under black locust plantation forest, natural forest, cropland, and shrubland. They only found groundwater recharge under cropland while no sign of recharge under shrubland and forestland. Another two studies estimated a recharge rate of $33-71 \mathrm{~mm}$ per year (or $6-12 \%$ of the mean annual precipitation) and $100 \mathrm{~mm}$ (or $22 \%$ the mean annual precipitation) beneath croplands and natural grassland (Huang et al. , 2017; Huang \& Pang, 2011), indicating promising seepage formation. It is thus can be assumed that black locust plantation generally prevents seepage and groundwater recharge, causing soil desiccation and groundwater decline in the long run.

In summary, despite the advantages of black locust in terms of soil erosion control, soil nutrient improvement (i.e., N-fixation) and drought resistance, the field studies across the Loess Plateau provided clear evidence that the black locust plantation forests with understory vegetation dry up soils and prevent groundwater recharge. The considerable water consumption of understory vegetation made a great contribution to the excessive water use of black locust forests. Long-term lack of soil water replenishment from precipitation will weaken soils' capacity to support plant growth, sustain vegetation restoration, and manage soil erosion control. Water-saving strategies of plantation forests are needed for the soil erosion control of the Loess Plateau.

\subsection{Hydrological Response at the Watershed Scale}

Afforestation has positive effects on watershed health, including reducing soil erosion and associated water pollution and enhancing terrestrial carbon sequestration. China has the largest plantation forest area in the world (Payn et al. , 2015); however, the hydrological consequences of such decade-long afforestation on eroded and degraded lands are rather unclear at the watershed scale (Fenget al. , 2012). For example, changes in water yield and ET can seriously affect the regional distribution of available water resources that may have adverse effects on water security in arid-prone areas. Paired watershed studies on the Loess Plateau showed that the annual runoff has dropped by $25-32 \%$ in afforested watersheds and the reduction of annual runoff increased with the age of planted trees (Huang et al. , 2003a, 2003b).

Budyko framework is a widely used tool for assessing the interlinkages of climatic and land surface characteristics and their feedback on watershed-scale water balance. It has been applied in the loess region to quantify the hydrological responses to land cover change and climate variability. Application of Budyko framework by Gao et al. (2016) in 15 major watersheds revealed that the annual streamflow and runoff coefficient in 14 of the 15 watersheds have decreased notably over four decades from 1961 to 2009. The land cover change resulted from the forestry development strategy of GGP took the main responsibility for the reduction. Similar conclusions are drawn from the Budyko-based assessment in 12 watersheds before and after 1999 (Li et al. , 2016b) and the estimated runoff coefficients of different land-uses (Zhang et al. , 2014). These results agree with the findings of a set of meta-analyses of the long-term monitoring records across 
many watersheds in the Loess Plateau (Bi et al. , 2014; Feng et al. , 2012; Hu et al. , 2017; Sun et al. , 2006; Wanget al. , 2011a, 2015, 2011b; Zhang et al. , 2015, 2008). A study in 53 watersheds found that when forest coverage [?] $25 \%$ of the watershed area, the mean annual streamflow is negatively correlated $\left(\mathrm{r}^{2}=\right.$ 0.6 ) with the forest coverage, namely the streamflow decrease significantly as forest cover increases (Wanget al. , 2015). Feng et al. (2012) indicated that water yield in $38 \%$ of the loess area has experienced a decline (1-48 $\mathrm{mm}$ per year) due to land cover change alone; the relative water yield losses (in \%) were very severe in dry years. Further forestland specific estimations suggest that forestland has a higher annual ET and a lower annual runoff than non-forestland; the average water yield loss from afforestation is likely to be about $50 \mathrm{~mm}$ per year in the semi-arid loess region (Sunet al. , 2006; Wang et al. , 2011b). Other studies also showed that afforestation-water yield relationships are variable with the size of watersheds; large watersheds involve many other interacting factors rather than vegetation, thus may mask the effects of forest cover on water resources (Bi et al. , 2014; Zhang et al. , 2014).

There is a general rising trend of ET over the Loess Plateau since the implementation of GGP. During the period from 2000 to 2012, the annual ET greatly increased by $3.4 \mathrm{~mm}$ per year, which outpaced the increased rate of $\mathrm{P}$ with $2.0 \mathrm{~mm}$ per year, implying a heightened pressure of water shortage (Jin et al. , 2017). The rise of ET is primarily driven by the enlarged LAI or the increased net primary productivity (NPP) as a result of large-scale vegetation greening (Feng et al. , 2016; Jinet al. , 2017; Li et al. , 2016a). Feng et al. (2016) estimated an NPP threshold of $400+-5 \mathrm{~g} \mathrm{C} \mathrm{m}^{-2} \mathrm{yr}^{-1}$ for the Loess Plateau based on the regional water demand; the current NPP in the Loess Plateau is already close to this limit, thus jeopardise regional water security. The investigation results of $\mathrm{Hu}$ et al. (2017) affirmed that no great difference exists among grassland, shrubland, and forests for soil erosion control and sediment reduction within the overall vegetation restoration; yet, shrubland and forests achieve a comparable result with higher water costs than grassland, suggesting that grassland is a more beneficial choice for balancing water provision and soil conservation.

Despite some evidence that afforestation has positive effects on reducing peak flow (related to floods) during storm events (Huanget al. , 2003a, 2003b), there is also some preliminary evidence on the reduction of annual and seasonal baseflow (i.e., the portion of water yield sourced from groundwater) across watersheds in the Loess Plateau (Dou et al. , 2009; Huang \& Zhang, 2004; Wu et al. , 2019). We thus argue that extensive afforestation over several decades has caused serious consequences for water management and sustainable development of dryland China. Continuous afforestation without an additional water-saving strategy in soil erosion management will lead to a disservice of water provision for areas that already suffer from severe water shortage.

Implications for Actions and Policy to Combat Soil Erosion

\subsection{Negative Water Impacts of Soil Erosion Control through Afforestation}

GGP uses planting trees to control soil erosion as forests create ground surface roughness, improve soil physical health (e.g., soil aggregation, pore structures, and hydraulic properties) (An et al. , 2010; Yuet al. , 2015) and enhance soil organic carbon through organic matter inputs and nutrient cycling (Smith, 2008), thus are beneficial for restoring soil functions to resist soil erosion and regulate climate change. However, they also alter rainfall partitioning and water cycling processes (e.g., ET and infiltration), resulting in an interplay of soil and hydrological processes and creating trade-off on water supply. Therefore, while forests reduce soil erosion and increase soil and biomass carbon sequestration, they also cause local and regional water shortages (Wang et al. , 2012; Bryan et al., 2018, Yuan et al. , 2018). The root cause of such undesirable results is sector-oriented policy and measures, namely, the implemented GGP policy and afforestation measures were originally designed for soil resources, specifically protecting soil from erosion and improving soil carbon. The increase of forest cover reduced soil erosion in past decades very effectively due to several hydrodynamic and hydrological effects (Wanget al. , 2017b). However, it had not taken the potential long-term impacts on the water resources into full consideration (Zhang \& Schwarzel, 2017b). This led to undesired water loss as a side-effect. Apart from this, more intense warming and frequent drought and floods are projected for northern China, including the Loess Plateau (Piaoet al. , 2010), which is likely to make the water supply from rivers in northern China more unstable and scarcer, further worsening the water deficiency in northern 
China. To ensure soil erosion control and adequate levels of water supply, at both local and regional scales, additional water-conserving measures are needed to refine the current GGP policy to manage the competition of the ecological functions of forests to conserve soil and regulate climate and water with a minimal trade-off.

\subsection{Critical Interventions to Reinforce Co-benefits}

Studies on on-site and off-site hydrological impacts of afforestation reveal that the ET of plantation forests needs to be better controlled to lower water consumption, particularly the understory while preventing soil erosion. Possible measures are to apply adaptive vegetation management. Ground coverage is key to reduce soil erosion; the intensity of soil erosion decreases with the increase of ground cover. Past study on the Loess Plateau indicated that there is almost no soil erosion if the ground coverage reaches $60 \%$ to $70 \%$ (Hou et al. , 1996; Wei, 2010). Therefore, maintaining a certain level of ground cover is key to control soil erosion on the Loess Plateau. Besides, forest (overstory) water consumption is determined by forest density and LAI. To cope with the additional challenge to ensure a certain level of water yield at watershed scales, forest management practices are needed for optimising stand structure and constraining LAI to prevent excessive water update. For example, research in the mountainous area of the Loess Plateau showed that a rational forest density of 1000 - 1200 trees/ha can effectively prevent soil erosion, lower ET to maintain adequate water yield, and sustain high vegetation biomass to sequester carbon under and above the ground (Wang et al. , 2017c).

Forest management has not been considered as a core issue of afforestation in GGP; it presents yet a very critical point to create water and climate co-benefits in controlling soil erosion. For example, a payment (also known as 'eco-compensation') up to seven years (equivalent to 22,500 RMB/ha) and free seedlings are provided to GGP participants for converting their degraded farmland to forestland in the Loess Plateau (Zhen \& Hu, 2017). With the payment, the structure of the rural income has changed; the proportion of cultivation-based income has dropped significantly while the portion sourced from afforestation and livestock breeding became larger. This brought more economic benefits to the GGP participants during the period of payment. However, in some cases, they suffer more economic loss since the payment stops after seven years (Liu et al. , 2014). Additional payment for forest management could offer an extra incentive to the GGP participants for maintaining long-term ecological benefits whereas meeting their economic interests, thereby particularly relevant to soil erosion control and water regulation. Moreover, we must be aware that many GGP participants do not have suitable knowledge and skills for forest management. Trainings, technical support and extension services are vital to landowners for applying proper forest management.

Conclusion

GGP's measure to increase forest cover for reducing soil erosion removes a large amount of water from the terrestrial ecosystem to the atmosphere. The undesired water loss will progressively dry up the soil and deteriorate soil health thus further cause soil erosion in the long run, in addition to a water crisis. Sustainable forest management is a critical linkage to mitigate the trade-off between soil conservation and water provision in GGP. Lack of suitable incentives discourages stakeholders from managing forests sustainably. Our work highlights the interconnected characters of soil resources to climate and water services, but they are not fully considered in the policy. A holistic understanding of the soil-water-climate nexus is vital for inclusive policy development to reinforce the water and climate co-benefits in actions to address soil erosion. A multi-dimensional and -scale trade-off analysis can facilitate decision-making to avoid risks of losing other ecosystem services, while incentive schemes are useful to motivate stakeholders for sustainable soil and water management. Our work provides lessons-learned to the global long-term greening efforts in the degraded arid environment. We strongly recommend careful hydrological evaluation for drylands if tree-planting is used for soil conservation with wishful climate and water co-benefits.

Acknowledgments

We thank the financial supports provided by the Deutsche Forschungsgemeinschaft (DFG Schw1448-3/1), the German Federal Ministry of Education and Research (BMBF-IPSWaT), and UNU-FLORES (MuLu). 
Conflict of Interest Statement : The authors declare no conflict of interest.

Reference:

An S, Mentler A, Mayer H, Blum WEH. 2010. Soil aggregation, aggregate stability, organic carbon and nitrogen in different soil aggregate fractions under forest and shrub vegetation on the Loess Plateau, China.CATENA 81 : 226-233. DOI: 10.1016/j.catena.2010.04.002

Bi C, Bi H, Sun G, Chang Y, Gao L. 2014. Scale effects and variability of forest-water yield relationships on the Loess Plateau, China. The Forestry Chronicle 90 : 184-191

Borrelli P, Robinson DA, Fleischer LR, Lugato E, Ballabio C, Alewell C, Meusburger K, Modugno S, Schutt B, Ferro V, Bagarello V, Oost KV, Montanarella L, Panagos P. 2017. An assessment of the global impact of 21st century land use change on soil erosion. Nature Communications 8 : 1-13. DOI: 10.1038/s41467-01702142-7

Bryan BA, Gao L, Ye Y, Sun X, Connor JD, Crossman ND, Stafford-Smith M, Wu J, He C, Yu D. 2018. China's response to a national land-system sustainability emergency. Nature 559 : 193-204

Deng L, Yan W, Zhang Y, Shangguan Z. 2016. Severe depletion of soil moisture following land-use changes for ecological restoration: Evidence from northern China. Forest Ecology and Management 366 : 1-10. DOI: $10.1016 /$ j.foreco.2016.01.026

Dou L, Huang M, Hong Y. 2009. Statistical assessment of the impact of conservation measures on streamflow responses in a watershed of the Loess Plateau, China. Water resources management 23 : 1935-1949

FAO, ITPS. 2015. Status of the World's Soil Resources (SWSR) - Main report . Food and Agriculture Organization of the United Nations and Intergovernmental Technical Panel on Soils: Rome, Italy

Feng X, Fu B, Piao S, Wang S, Ciais P, Zeng Z, Lu Y, Zeng Y, Li Y, Jiang X. 2016. Revegetation in China's Loess Plateau is approaching sustainable water resource limits. Nature Climate Change6 : 1019-1022

Feng XM, Sun G, Fu BJ, Su CH, Liu Y, Lamparski H. 2012. Regional effects of vegetation restoration on water yield across the Loess Plateau, China. Hydrol. Earth Syst. Sci. 16: 2617-2628 16 : 2617-2628

Fu B, Liu Y, Lu Y, He C, Zeng Y, Wu B. 2011. Assessing the soil erosion control service of ecosystems change in the Loess Plateau of China.Ecological Complexity 8 : 284-293

Gao G, Fu B, Wang S, Liang W, Jiang X. 2016. Determining the hydrological responses to climate variability and land use/cover change in the Loess Plateau with the Budyko framework. Science of The Total Environment 557-558 : 331-342. DOI: 10.1016/j.scitotenv.2016.03.019

Gates JB, Scanlon BR, Mu X, Zhang L. 2011. Impacts of soil conservation on groundwater recharge in the semi-arid Loess Plateau, China.Hydrogeology Journal 19 : 865

Gustafsson M, Creed I, Dalton J, Gartner T, Matthews N, Reed J, Samuelson L, Springgay E, Tengberg A. 2019. Gaps in science, policy and practice in the forest-water nexus. Unasylva 251: Forests: nature-based solutions for water $\mathbf{2 5 1}$ : 36

Hou X, Bai G, Cao Q. 1996. Study on benefits of soil and water conservation of forest and its mechanism in loess hilly region.3 : 98-103

$\mathrm{Hu}$ J, Lu Y, Fu B, Comber AJ, Harris P. 2017. Quantifying the effect of ecological restoration on runoff and sediment yields: a meta-analysis for the Loess Plateau of China. Progress in Physical Geography41 : $753-774$

Huang M, Gallichand J, Zhang P. 2003a. Runoff and sediment responses to conservation practicesL Loess Plateau of China. JAWRA Journal of the American Water Resources Association 39 : 1197-1207 
Huang M, Zhang L. 2004. Hydrological responses to conservation practices in a catchment of the Loess Plateau, China. Hydrological Processes 18 : 1885-1898

Huang M, Zhang L, Gallichand J. 2003b. Runoff responses to afforestation in a watershed of the Loess Plateau, China. Hydrological Processes 17 : 2599-2609

Huang T, Pang Z. 2011. Estimating groundwater recharge following land-use change using chloride mass balance of soil profiles: a case study at Guyuan and Xifeng in the Loess Plateau of China.Hydrogeology Journal 19 : 177-186

Huang T, Pang Z, Liu J, Ma J, Gates J. 2017. Groundwater recharge mechanism in an integrated tableland of the Loess Plateau, northern China: insights from environmental tracers. Hydrogeology Journal25 : 2049 2065. DOI: $10.1007 / \mathrm{s} 10040-017-1599-8$

Jia X, Shao M, Zhu Y, Luo Y. 2017. Soil moisture decline due to afforestation across the Loess Plateau, China. Journal of Hydrology 546 : 113-122. DOI: 10.1016/j.jhydrol.2017.01.011

Jian S, Zhao C, Fang S, Yu K. 2015. Effects of different vegetation restoration on soil water storage and water balance in the Chinese Loess Plateau. Agricultural and Forest Meteorology 206 : 85-96. DOI: 10.1016/j.agrformet.2015.03.009

Jiao L, Lu N, Fu B, Wang J, Li Z, Fang W, Liu J, Wang C, Zhang L. 2018. Evapotranspiration partitioning and its implications for plant water use strategy: Evidence from a black locust plantation in the semi-arid Loess Plateau, China. Forest Ecology and Management 424 : 428-438. DOI: 10.1016/j.foreco.2018.05.011

Jin Z, Liang W, Yang Y, Zhang W, Yan J, Chen X, Li S, Mo X. 2017. Separating Vegetation Greening and Climate Change Controls on Evapotranspiration trend over the Loess Plateau. Scientific Reports 7 : 1-15. DOI: $10.1038 / \mathrm{s} 41598-017-08477-\mathrm{x}$

Kimura R, Fan J, Zhang X, Takayama N, Kamichika M, Matsuoka N. 2006. Evapotranspiration over the Grassland Field in the Liudaogou Basin of the Loess Plateau, China. Acta Oecologica 29 : 45-53. DOI: 10.1016/j.actao.2005.07.003

Li S, Liang W, Fu B, Lu Y, Fu S, Wang S, Su H. 2016a. Vegetation changes in recent large-scale ecological restoration projects and subsequent impact on water resources in China's Loess Plateau. Science of The Total Environment 569-570 : 1032-1039. DOI: 10.1016/j.scitotenv.2016.06.141

Li Y, Liu C, Zhang D, Liang K, Li X, Dong G. 2016b. Reduced runoff due to anthropogenic intervention in the Loess Plateau, China. Water 8 : 458

Liang H, Xue Y, Li Z, Wang S, Wu X, Gao G, Liu G, Fu B. 2018. Soil moisture decline following the plantation of Robinia pseudoacacia forests: Evidence from the Loess Plateau. Forest Ecology and Management 412 : 62-69. DOI: $10.1016 /$ j.foreco.2018.01.041

Liu G, Tsunekawa A, Dang X, Du S. 2014. Future development-related challenges on the Loess Plateau. Restoration and Development of the Degraded Loess Plateau, China . Springer, 267-282

Ma C, Luo Y, Shao M, Li X, Sun L, Jia X. 2017. Environmental controls on sap flow in black locust forest in Loess Plateau, China.Scientific Reports 7 : 1-12. DOI: 10.1038/s41598-017-13532-8

Payn T, Carnus J-M, Freer-Smith P, Kimberley M, Kollert W, Liu S, Orazio C, Rodriguez L, Silva LN, Wingfield MJ. 2015. Changes in planted forests and future global implications. Forest Ecology and Management352 : $57-67$

Piao S, Ciais P, Huang Y, Shen Z, Peng S, Li J, Zhou L, Liu H, Ma Y, Ding Y. 2010. The impacts of climate change on water resources and agriculture in China. Nature 467:43-51

Podlasly C, Schwarzel K. 2013. Development of a continuous closed pipe system for controlling soil temperature at the lower boundary of weighing field lysimeters. Soil Science Society of America Journal $7 \mathbf{7}$ : 
Schwarzel K, Zhang L, Montanarella L, Wang Y, Sun G. 2020. How afforestation affects the water cycle in drylands: A process-based comparative analysis. Global Change Biology 26 : 944-959. DOI: $10.1111 /$ gcb. 14875

Schwarzel K, Zhang L, Strecker A, Podlasly C. 2018. Improved Water Consumption Estimates of Black Locust Plantations in China's Loess Plateau. Forests 9 : 201

Smith P. 2008. Land use change and soil organic carbon dynamics. Nutrient Cycling in Agroecosystems 81 : $169-178$

Sommer S, Cherlet M, Ivits E. 2017. Global Land Outlook - First Edition. UNCCD: Bonn, Germany

Song X, Peng C, Zhou G, Jiang H, Wang W. 2014. Chinese Grain for Green Program led to highly increased soil organic carbon levels: A meta-analysis. Scientific Reports 4 : 1-7. DOI: 10.1038/srep04460

Springgay E, Casallas Ramirez S, Janzen S, Vannozzi Brito V. 2019. The Forest-Water Nexus: An International Perspective. Forests10 : 915. DOI: 10.3390/f10100915

Sun G, Zhou G, Zhang Z, Wei X, McNulty SG, Vose JM. 2006. Potential water yield reduction due to forestation across China. Journal of Hydrology 328 : 548-558

UNDESA. 2019. World Population Prospects 2019: Highlights . New York, USA

Wang S, Fu B-J, He C-S, Sun G, Gao G-Y. 2011a. A comparative analysis of forest cover and catchment water yield relationships in northern China.Forest Ecology and Management 262 : 1189-1198. DOI: 10.1016/j.foreco.2011.06.013

Wang X, Bi H, Song Q, Lu S. 2015. Influence of Forest Coverage on Basin Runoff in China's Loess Plateau. Polish Journal of Environmental Studies $\mathbf{2 4}$

Wang X, Jiao F, Li X, An S. 2017a. The Loess Plateau. In: Zhang L and Schwarzel K (eds) Multifunctional Land-Use Systems for Managing the Nexus of Environmental Resources . Springer International Publishing: Cham, 11-27. DOI: 10.1007/978-3-319-54957-6_2

Wang Y, Bonell M, Feger K-H, Yu P, Xiong W, Xu L. 2012. Changing forestry policy by integrating water aspects into forest/vegetation restoration in dryland areas in China. Bull. Chin. Acad. Sci2626 : 59-67

Wang Y, Yu P, Feger K-H, Wei X, Sun G, Bonell M, Xiong W, Zhang S, Xu L. 2011b. Annual runoff and evapotranspiration of forestlands and non-forestlands in selected basins of the Loess Plateau of China.Ecohydrology $4: 277-287$

Wang Y, Yu P, Wang J, Xu L, Feger K-H, Xiong W. 2017b. Multifunctional forestry on the Loess Plateau. Multifunctional Land-Use Systems for Managing the Nexus of Environmental Resources . Springer, 79-107

Wang Y, Yu P, Xiong W, Tian Y, Yu Z, Hu Y, Xu L, Zuo H, Schwarzel K. 2017c. Multifunctional Forestry and Forest Management: Eco-hydrological Considerations. In: Zhang L and Schwarzel K (eds) Multifunctional Land-Use Systems for Managing the Nexus of Environmental Resources . Springer International Publishing: Cham, 109-135. DOI: 10.1007/978-3-319-54957-6_7

Wei T. 2010. Forest coverage of small watershed and stand density in the gullied-hilly region on Loess Plateau. Journal of Arid Land Resources and Environment 2

Wu J, Miao C, Duan Q, Lei X, Li X, Li H. 2019. Dynamics and attributions of baseflow in the semiarid Loess Plateau. Journal of Geophysical Research: Atmospheres 124 : 3684-3701

Xin Z, Yu B, Han yuguo. 2015. Spatiotemporal Variations in Annual Sediment Yield from the Middle Yellow River, China, 1950-2010. Journal of Hydrologic Engineering 20 : 04014090. DOI: 10.1061/(ASCE)HE.19435584.0001113 
Yang F, Zhang Q, Wang R, Zhou J. 2014. Evapotranspiration Measurement and Crop Coefficient Estimation over a Spring Wheat Farmland Ecosystem in the Loess Plateau. PLoS ONE 9 . DOI: 10.1371/journal.pone.0100031

Yu M, Zhang L, Xu X, Feger K-H, Wang Y, Liu W, Schwarzel K. 2015. Impact of land-use changes on soil hydraulic properties of Calcaric Regosols on the Loess Plateau, NW China. Journal of Plant Nutrition and Soil Science 178 : 486-498

Yuan Z, Yan D, Yang Z, Xu J, Huo J, Zhou Y, Zhang C. 2018. Attribution assessment and projection of natural runoff change in the Yellow River Basin of China. Mitigation and adaptation strategies for global change 23 : 27-49

Zhang L, Podlasly C, Feger K-H, Wang Y, Schwarzel K. 2015. Different land management measures and climate change impacts on the runoff-A simple empirical method derived in a mesoscale catchment on the Loess Plateau. Journal of arid environments 120 : 42-50

Zhang L, Podlasly C, Ren Y, Feger K-H, Wang Y, Schwarzel K. 2014. Separating the effects of changes in land management and climatic conditions on long-term streamflow trends analyzed for a small catchment in the Loess Plateau region, NW China. Hydrological Processes 28 : 1284-1293

Zhang L, Schwarzel K. 2017a. China's Land Resources Dilemma: Problems, Outcomes, and Options for Sustainable Land Restoration.Sustainability 9 : 2362

Zhang L, Schwarzel K. 2017b. Applying Multifunctionality to Address the Challenges and Benefits of LandUse Management. Multifunctional Land-Use Systems for Managing the Nexus of Environmental Resources . Springer, 1-9

Zhang Q, Jia X, Shao M, Zhang C, Li X, Ma C. 2018a. Sap flow of black locust in response to short-term drought in southern Loess Plateau of China. Scientific reports 8 : 1-10

Zhang S, Yang D, Yang Y, Piao S, Yang H, Lei H, Fu B. 2018b. Excessive afforestation and soil drying on China's Loess Plateau. Journal of Geophysical Research: Biogeosciences 123 : 923-935

Zhang X, Zhang L, Zhao J, Rustomji P, Hairsine P. 2008. Responses of streamflow to changes in climate and land use/cover in the Loess Plateau, China. Water Resources Research 44

Zhen L, Hu J. 2017. The Land-Use Protection Policy in China. In: Zhang L and Schwarzel K (eds) Multifunctional Land-Use Systems for Managing the Nexus of Environmental Resources. Springer International Publishing: Cham, 29-51. DOI: 10.1007/978-3-319-54957-6_3 


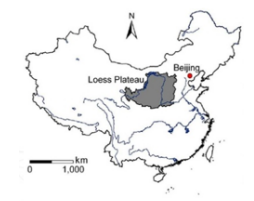

The Loess Plateau

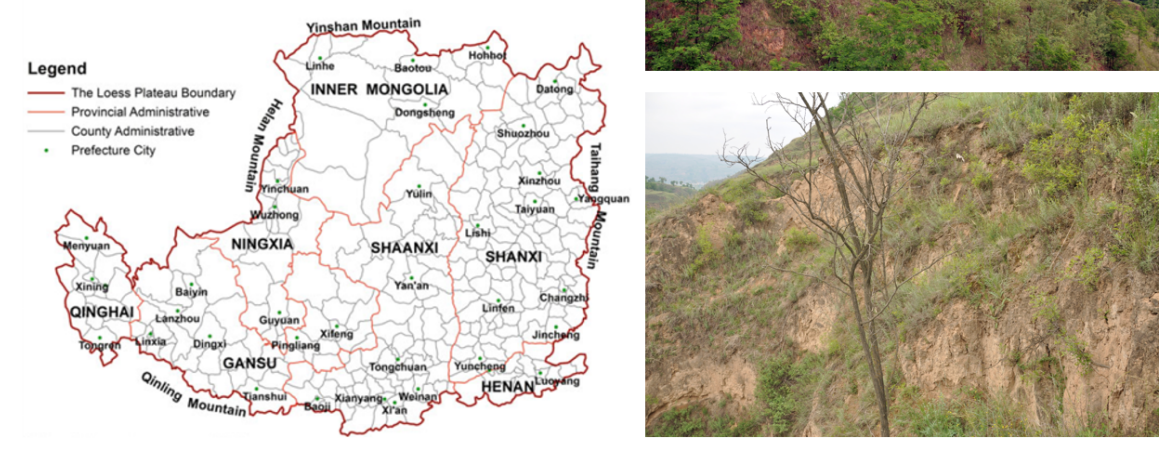

